\title{
CLIMATE AS A RESULT OF THE EARTH HEAT REFLECTION
}

\author{
J. Barkāns, D. Žalostība \\ Riga Technical University, the Institute of Power Engineering, \\ 1 Kronvalda Blvd., Riga LV-1010, LATVIA \\ e-mail:diana@eef.rtu.lv
}

\begin{abstract}
The authors show that the mean global temperature - and, therefore, climate is determined mainly by the reflected portion of the total heat received from the Sun. The heat reflected directly by infra-red radiation is insufficient for maintenance of the temperature necessary for the Earth life, since it is limited by absorption windows created by green-house gases (mainly water molecules). The deficient heat is transported by a strong vertical convective air stream - a component of the total air circulation. This heat - limited only by Newton's law - is delivered to the upper troposphere layers not containing water molecules, from where it is dissipated, practically unlimitedly, at the infra-red radiation wavelengths corresponding to cooled media. The convection, in compliance with Newton's law, creates a negative feedback, which stabilizes the processes of temperature changes on the Earth reducing them by half.
\end{abstract}

Key words: climate change.

\section{INTRODUCTION}

Today as never before the problem of climate changes has been the focus of attention of the scientific world community. Many disciplines of physics astrophysics, quantum theory, physics of atmosphere, meteorology, geophysics, spectroscopy as well as power engineering and mathematics continue an active search for the causes of this phenomenon.

As known, the progress of science relies upon the facts obtained during observations of natural phenomena. When the volume of such facts, having been analyzed in full, reaches some critical level the attempts of their theoretical interpretation begin. By now, the climate change research activities have borne some fruit. Principles of rational energy utilisation have been recognised and worked out, and the energy saving technologies developed. In some areas, e.g. in the household sectors of developed countries, the energy consumption has decreased by up to $50 \%$. The main preoccupation of the power industry is now the efficiency improvement of energy generating equipment and implementation of purification constructions to protect the atmosphere against harmful pollutions. Start was made for development of distributed cogeneration and alternative generation sources. Correspondingly, the related branches of business are rapidly developing.

However, a deep insight into these natural phenomena has not been gained in fact, the long-term temperature rise in the $20^{\text {th }}$ century had started fifty years before the beginning of enhanced $\mathrm{CO}_{2}$ emissions into the atmosphere. 
In a previous part of our research into the behaviour of river waterflows we employed the discrete wavelet spectral analysis with the aim to compare variations in them with those in the intensities of processes occurring on the Sun [1].

Briefly, this could be reviewed as follows.

In the wavelet analysis we divided the mentioned processes into separate frequency groups, and in each of them similarities between the two categories of phenomena - the variations in the world's river waterflows and in the Sun's intensities - were revealed. Clearly, this analysis had to be correlated with the temperature changes on the Earth. As a result, in eight frequency channels a close relationship between the global temperature and the Sun's intensity variations was established [2].

The principal result was connected with a fragment of the longest millenary cycle period of 300-year observations over the Sun during which natural variations in the solar processes were revealed, and it was found out that the 5-90-year temperature cycles coincide with the corresponding cycles of solar activity. It was established that the temperature rise of the last century that occurred on the Earth is mainly explainable by millenary solar activity variation cycles [2]; this result was complemented by the information obtained while studying the ice cores from Greenland and Antarctic glaciers. All this has given us a notion of similar processes that took place in the A.D. $10^{\text {th }}$ century as well as in the $2^{\text {nd }}, 13^{\text {th }}$, and $30^{\text {th }}$ B.C. [3].

A most important fact related to the astrophysics was established: in 1910, the phase of the global temperature variation process changed to the opposite, which, under the conditions of constant insolation, is evidence in favour of the role played by the magnetic field of the Sun [2]. So, if before the phase change at the solar intensity rise the global temperature had been varying correspondingly, then after that in the high-frequency groups it varied in anti-phase. At the same time, in 160-1000-year cycles these variations proceeded in phase, as before. This explains the fall in temperature - rather mysterious and seemingly contradictory to those conditions - in 1935-1975 against the background of its monotone rise [2].

Concerning the dependence between the variations of solar magnetic field and those of global temperatures, a hypothesis exists, according to which in the atmosphere the trajectories of cosmic radiation particles undergo variations caused by the interaction between magnetic fields of the Sun and the Earth. These particles act as centres of condensation for the atmospheric water vapours (much like as it occurs in a Wilson's chamber), which, in turn, affects the global temperature.

This work poses additional questions as to the role of greenhouse gas effect in the mentioned above temperature variations. Therefore, it is worthwhile to review this problem based on the known data.

\section{CHARACTER OF THE GLOBAL HEAT TRANSFER}

As is known, the Earth receives heat from the Sun mainly in the visible light region. In turn, it partially gives up the heat into the space. The heat removal from heated bodies proceeds in two ways (or channels): radiative and convective.

The heat is reflected through the troposphere - the lower part of the atmosphere at a height of $8-10 \mathrm{~km}$ in the temperate latitudes and of $16 \mathrm{~km}$ in the equatorial zone. In this zone, apart from nitrogen and oxygen, there are water 
molecules (in a 6-7 km high layer) affected by the infra-red electro-magnetic radiation, and, besides, $\mathrm{CO}_{2}$, methane, ozone, and some other gases.

\section{Heat transfer to the atmosphere by radiation}

The radiation density, $\mathrm{W} / \mathrm{m}^{2}$, in the infra-red region is determined in compliance with Stefan-Bolzmann's law:

$$
E=\sigma T^{4},
$$

where $T_{1} ; \sigma-$ are, respectively, the temperature on a warm surface and the StefanBolzmann constant.

The relationship between radiation density $E$, absolute temperature $T$ and wavelength $\lambda$ is defined by the Planck equation containing an exponential function:

$$
E=\frac{2 \pi C_{1}}{\lambda^{5}\left(e^{C_{2} / \lambda T}-1\right)^{7}}
$$

where $C_{1}=0.50544 \cdot 10^{-16} \mathrm{~W} / \mathrm{m}^{2} ; C_{2}=1.4388 \cdot 10^{-2} \mathrm{~m} \cdot \mathrm{K}$.

The wavelength corresponding to the maximum radiation $E_{\max }$ at the absolute temperature $T$ is found from the Winn's relationship:

$$
\lambda_{\max } T=C,
$$

where $C=2.8978 \cdot 10^{-3} \mathrm{~m} \cdot \mathrm{K}$.

At lower temperatures the radiation shifts towards a longer wave region (see Fig. 1).

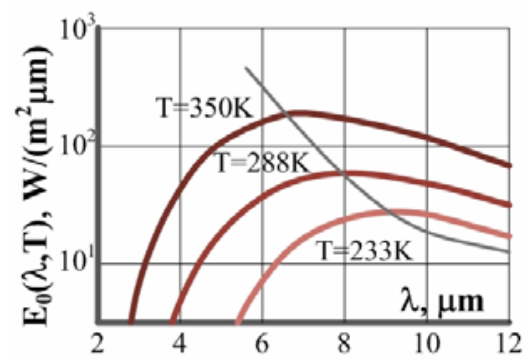

Fig. 1. Infrared radiation wavelengths $v$ s. temperature.

The essence of this process could be illustrated by the operation of a solar collector (Fig. 2).

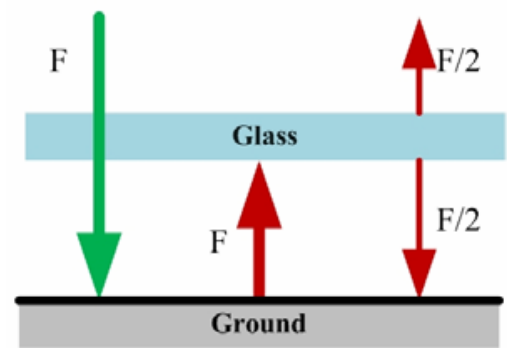

Fig. 2. Scheme of the solar collector operation. 
Such a collector presents a glazed box containing a water circulation system. Glass is transparent for visible radiation and only partially transparent for infra-red radiation, thus allowing some energy to be accumulated in the collector. In the atmosphere, the infra-red radiation is trapped not in a thin layer but in the depth owing to the presence of molecules with dipole properties.

The radiation processes are studied by spectroscopy, from which it follows that to each of the dipole molecules reacting to radiation definite spectral lines correspond (see Fig. 3 [4]).

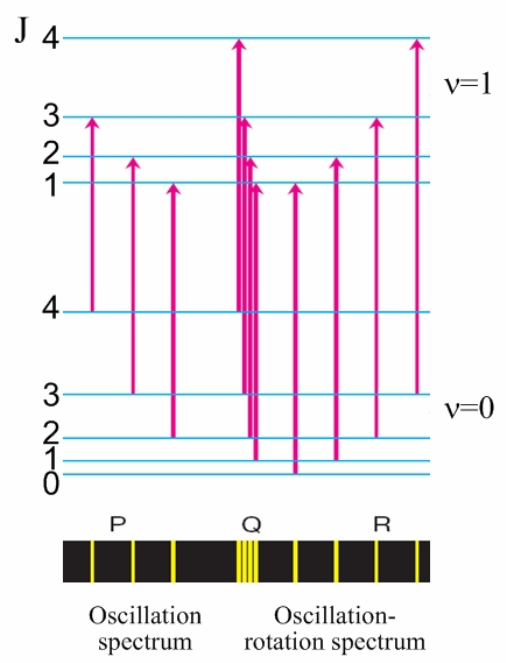

Fig. 3. Spectral lines of dipole molecules.

This phenomenon of the quantum mechanics, according to which the radiation transmission or absorption occurs, is connected with that similar to resonance.

Water vapour molecules under the infra-red radiation experience changes in three energy levels (Fig. 4 [4]).

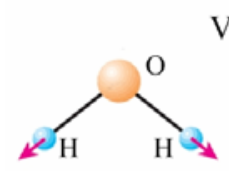

Symmetrical

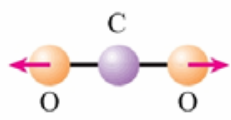

$v_{1}=1$
Valent

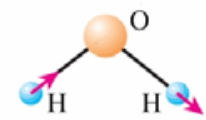

Asymmetrical

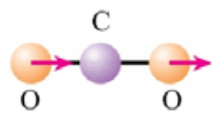

$v_{1}=3$
Deforming<smiles>NC=O</smiles>

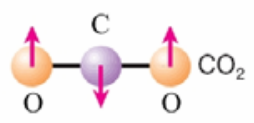

$v_{1}=2$

Fig. 4. Deformations of water and carbon dioxide gas molecules.

The first two - symmetrical and anti-symmetrical deformations of the bonds between hydrogen and oxygen atoms - cause oscillations. The third one is variation in the angle between the bonds (being $104.5^{\circ}$ at rest) followed by rotation [4]. In fact, the molecules in mutual collisions have indefinite motion velocity, $v$, 
which varies in the $\pm \Delta$ range (respectively, the maximum and minimum velocities being $v+\Delta$ and $v-\Delta$ ). In compliance with Doppler's effect, the spectral lines extend when responding to different velocities, thus transforming into bands with the profile characteristic of the so-called normal distribution. When such bands are overlapping they form absorption zones.

The properties, which are similar to those of resonance, correspond to definite frequency ranges - "windows". The corresponding absorption zones for water molecules have frequencies that discretely cover infra-red radiation in the following regions: $4.2-4.8 ; 5.2-8$ and $22-70 \mu \mathrm{m}$ [5]. These absorption zones form windows (shown in Fig. 5) whose effect depends on their saturation. For water molecules these are saturated in a wide region in which the atmosphere becomes practically opaque. The saturation for water absorption gradually decreases in the $14-22 \mu \mathrm{m}$ region, and in the $8.6-14 \mu \mathrm{m}$ region the atmosphere is transparent. Through such windows there leaves a portion of the solar energy accumulated by the Earth (shown in the figure by dark colour).

The gap that is seen in the transparent window corresponds to ozone and, partially, to oxygen molecules, which, at electronic shells being deformed at mutual molecular collisions, acquire weak dipolar properties.

Water molecules in the atmosphere are dominant in green-house gases. In the vaporous state their heat absorption is approximately $70 \%$, and in the condensed state (clouds) $-20 \%$ of the total. The rest $10 \%$ fall on other heat absorbing molecules existing in the atmosphere.

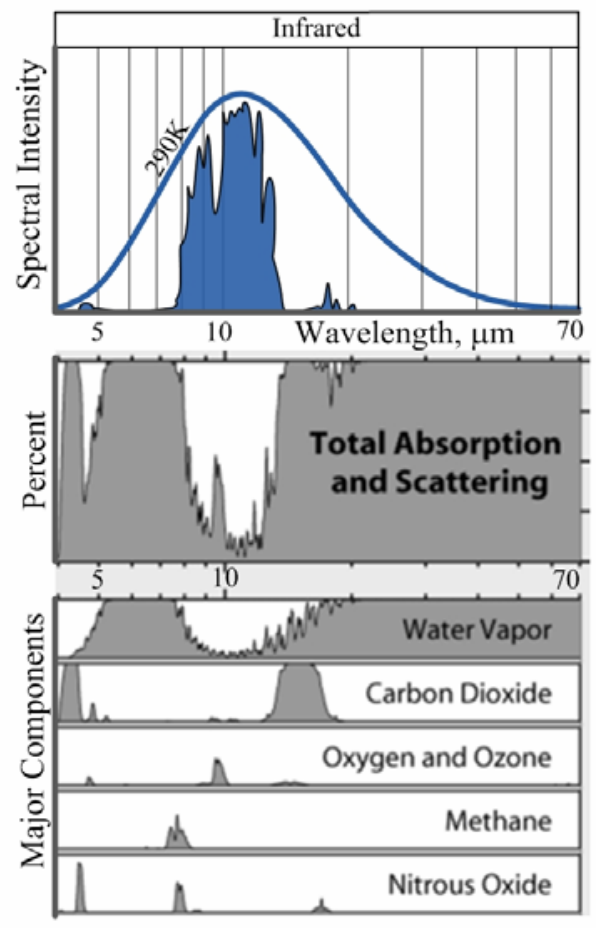

Fig. 5. Absorption zones of infra-red radiation. 
As concerns water molecules in the atmosphere, they are unstable. Under natural conditions, with the onset of a cold period, water is frozen out, which reduces the heat absorption and favours the outset of a glacial epoch. As known, during a period of 700 thousand years there were six glacial epochs. Each of them lasted approximately 100 thousand years, with ca 20ths-year interglacial epochs.

Carbon dioxide gas, whose molecules possess dipolar properties, is a stable green-house gas. At definite infra-red radiation wavelengths they acquire three unilateral and anti-symmetrical oscillation and oscillation-rotation deformations (see Fig. 3), which create a relatively narrow $(14-16 \mu \mathrm{m})$ absorption window. This wavelength interval is situated in the region of a decrease in the water molecule window saturation. Its absorption profile has a specific shape, which is shown in Fig. 6 [6]. To the spectral line consolidation at a frequency of $15 \mu \mathrm{m}$ the maximum absorption is corresponding to $\mathbf{Q}$ zone in the figure. To the rare spectral lines the absorption wings $\mathbf{R}$ and $\mathbf{P}$ correspond (higher and lower frequencies, respectively). In the general view of absorption windows it could be seen that $\mathbf{P}$ wing is overlapping the water absorption zone (Fig. 5).

The author of the mentioned work, Dr Heinz Hug (Wiesbaden, Germany), studied this problem on a physical model of $\mathrm{CO}_{2}$ absorption under infra-red radiation at laboratory conditions. The model allowed him to establish variations of $0.17 \%$ in absorption for $357 \mathrm{ppm}$ and double, i.e. $714 \mathrm{ppm}$ specific weights of this gas. Owing to the modelling possibilities, the problem deserves thorough investigation.

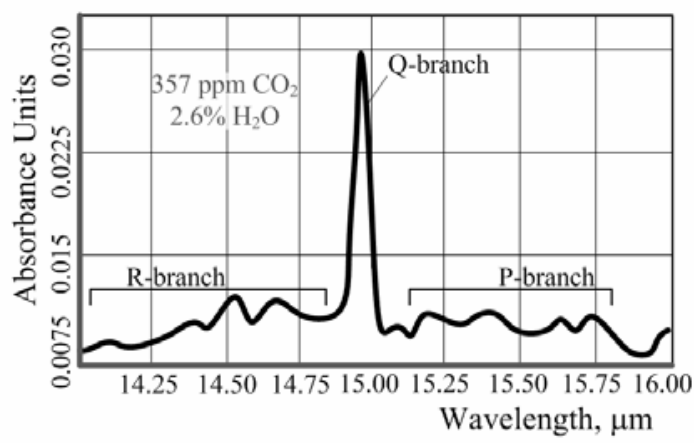

Fig. 6. The profile of $\mathrm{CO}_{2}$ absorption.

\section{BALANCE OF THE EARTH TEMPERATURE}

The global temperature balance is determined by the solar energy streams. Recall that the temperature of the Sun's surface is $5783 \mathrm{~K}$, its radius is $r_{s}=6.599 \cdot 10^{5} \mathrm{~km}$, and the Earth' radius is $r_{e}=6.378 \cdot 10^{3} \mathrm{~km}$. According to the Stefan-Bolzmann's law, the solar radiation stream is $\sigma T_{s}^{4}$, where $\sigma$ is the StefanBoltzmann constant, $5.6704 \cdot 10^{-8} \mathrm{Wm}^{2} \mathrm{~K}^{4}$. The mean distance between the Sun and the Earth is $r_{s e}=1.496 \cdot 10^{8} \mathrm{~km}$. The radiation stream reaching the Earth is proportional to the squared ratio of the Sun's radius and the mentioned distance $\left(r_{s} / r_{s e}\right)^{2}$. 
The solar energy received by the Earth could be defined as

$$
E_{s}=k_{1} \sigma T_{s}^{4} \pi r_{e}^{2}\left(r_{s} / r_{s e}\right)^{2} \text {. }
$$

The infra-red radiation energy reflected to the Universe is

$$
E_{r}=k_{2} \sigma T_{e}^{4} 4 \pi r_{e}^{2}
$$

In these equalities $k_{1}$ and $k_{2}$ are the portions of energy received and reflected by the Earth, respectively.

If we assume the Earth to be without atmosphere, all the solar energy streams reach its surface. In turn, also all the received energy is reflected back into the space $\left(k_{1}=k_{2}=1\right)$. In this case, the mean global temperature is found from the equality: $E_{e}=E_{s}$, from where we obtain:

$$
T_{e}=T_{s} \sqrt{\sqrt{\frac{k_{1}}{k_{2}}} \frac{r_{s}}{2 r_{s e}}}=272 \mathrm{~K} \text {, or }-1{ }^{\circ} \mathrm{C} .
$$

Since the Earth atmosphere absorbs the ultraviolet radiation from the Sun (see Fig. 7), its surface receives only a portion of the solar energy, and $k_{1}=0.78$.

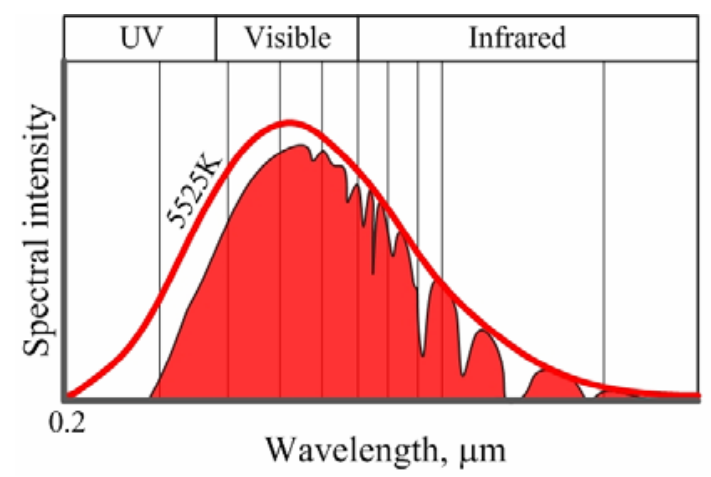

Fig. 7. Influence of the atmosphere on the solar radiation.

Not taking into account the green-house effect we obtain:

$$
T_{e}=T_{s} \sqrt{\sqrt{\frac{0.78}{1}} \frac{r_{s}}{2 r_{s e}}}=255 \mathrm{~K} \text {, or }-18{ }^{\circ} \mathrm{C} \text {. }
$$

Considering the limitations posed by the windows absorbing atmospheric IR radiation, into the space only a portion of the energy received is reflected, i.e. $k_{2} \approx 0.3$ (Fig. 5 ). In the case of heat energy transfer by purely infra-red radiation this temperature will be:

$$
T_{e}=T_{s} \sqrt{\sqrt{\frac{0.78}{0.3}} \frac{r_{s}}{2 r_{s e}}}=345 \mathrm{~K}, \text { or } 72{ }^{\circ} \mathrm{C} .
$$


If there be heat transfer by IR radiation only, the climate catastrophe should have taken place long ago. Factually observed average temperature value is $288 \mathrm{~K}$ or $+15{ }^{\circ} \mathrm{C}$. To ensure such temperature much more powerful heat removal is needed:

$$
k_{2}=k_{1} \frac{T_{s}^{4}}{T_{e}^{4}} \frac{r_{s}^{2}}{4 r_{s e}{ }^{2}}=0.78 \frac{5783^{4}}{288^{4}} \frac{1}{4}\left(\frac{6.599 \cdot 10^{5}}{1.496 \cdot 10^{8}}\right)^{2}=0.62,
$$

which cannot be ensured by radiation only.

The deficient portion of heat is delivered by the other channel - the convective one, through which the heat is transported by powerful vertical air streams to the upper troposphere layers not containing water vapour molecules bypassing the water absorbing windows. From there it is dissipated in the space, at the infra-red radiation wavelengths corresponding to cooled media.

In turn, the total heat transfer is the sum of radiative and convective components: $k_{2}=k_{r}+k_{c}$.

Therefore more than half of the necessary heat reflection to the space is provided by convection.

\section{Convective heat transfer}

Convective air streams in the atmosphere are formed by masses of warmed and incompact air that is vertically ascending from the Earth surface and, simultaneously, by descending masses of colder and denser air. The velocity of such vertical streams reaches $20-30 \mathrm{~m} / \mathrm{s}$. Energetic convective vertical streams, being a component of the total air circulation, permeate the whole atmosphere and reach the stratosphere, thus playing an important role in the heat exchange between the atmospheric layers and fulfilling the function of heat transfer into the Universe.

The heat removal by free convection of atmospheric air flows per area unit proceeds according to Newton's equality:

$$
e_{c}=\alpha \cdot T \text {, }
$$

where $T$ is the temperature on a warm surface, $\mathrm{K}$, and $\alpha$ is the convection heattransfer coefficient, $\mathrm{W} / \mathrm{m}^{2} \mathrm{~K}$.

The necessary heat removal corresponds to the ratio:

$$
\frac{\Delta E_{\%}}{\Delta T}=(62-30) /(72-15)=0.56\left(\% /{ }^{0} C\right) \text {. }
$$

The necessary heat reflection that cannot be ensured by the radiation channel is performed by convection. If, for example, as a result of changes in the solar radiation intensity a temperature rise occurs (as it was observed in the past century), then the carrying capacity of the convective channel increases corresponding to this rise, restricting it and creating a negative feedback that acts as stabilizer of these processes. In other words, this channel regulates the Earth temperature by reducing its changes.

$$
\Delta T=\frac{\Delta E_{r}}{\alpha \cdot 4 \pi r_{e}^{2}},
$$


where $\Delta E_{r}$ is the required heat energy removal, $\mathrm{W} / \mathrm{m}^{2}$.

The convective heat transfer is an inertial process with a time constant that is commensurable with the years in which the seasonal variations are equalized. A notion about the inertia of a convective channel could be received when studying, for example, the changes in the cyclic phase of integral river waterflows connected with overturn of the solar magnetic field. There is evidence that the phase change of river waterflows occurred in 1930 (see Fig. 8), i.e. 20 years after the temperature phase change in 1910 [1]. This could be explained by a long-lasting stationary process of climate change that should have taken place in this case.

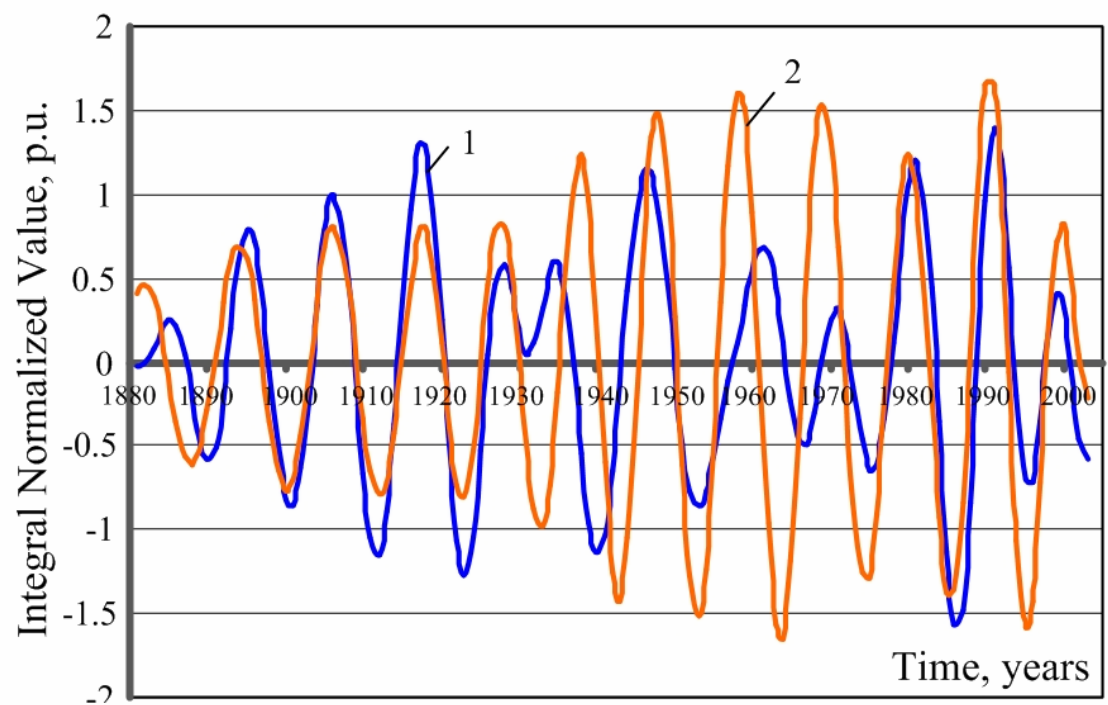

Fig. 8. Phase changes of river waterflows: comparison of discrete wavelet transform components $d_{3}$ : 1 - integral normalized value of the Daugava river's waterflow $v s$. years; 2 - integral normalized value of the Sun's intensity $v s$. years

The convection under consideration - a planetary horizontally-vertical air circulation - can be presented in the form of three air motion rings as follows [7].

First planetary circulation ring, in which the heat exchange proceeds between the warmed equator and cold poles, with heat transfer by vertical air motion components to the upper layers of troposphere (see Fig. 9). Having given up heat, the air is descending, streaming back towards the equator. Owing to the Earth rotation, these streams in Northern Hemisphere are east-bound and in Southern Hemisphere - west-bound.

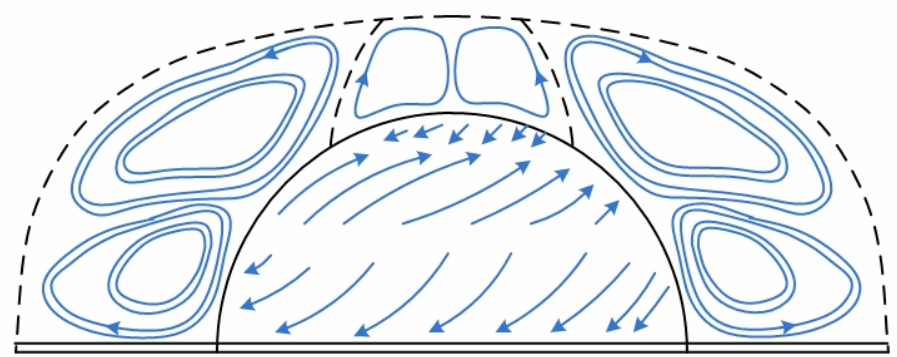

Fig. 9. Diagram of air streams in the atmosphere. 
Second planetary circulation ring, which in this latitude is formed by the accumulated air masses creating a zone of elevated pressure. From there the air masses are streaming in two directions determined by the Earth rotation (Coriolis') forces. A proportion of cooled air mass turns back to the equator forming northeastern winds (trade-winds) closing the second circle.

Third planetary circulation ring. This ring is formed by a second portion of air mass that continues to move in the northern direction, shifting to the east under the influence of Coriolis' forces. Here in the temperate latitudes south-east and east winds are formed. In high latitudes the air, having been cooled, descends and streams south, assuming a western direction of the motion. Having met with the air from temperate latitudes it ascends thus closing the third circle.

In reality, the described picture is influenced by the dry land's relief and oceanic surfaces. Such a land is rapidly heated up in summer, acting as a cooler, while the ocean possesses a greater inertia, and is functioning as a heater. In winter an opposite picture is observed. Therefore the whole picture is complemented by seasonal influence in the form of monsoons, which in winter and in summer blow in opposite directions.

Not concentrating our attention on local and short-term features, we can present the structure as shown in Fig. 10, which approximately characterizes the factors influencing climate.

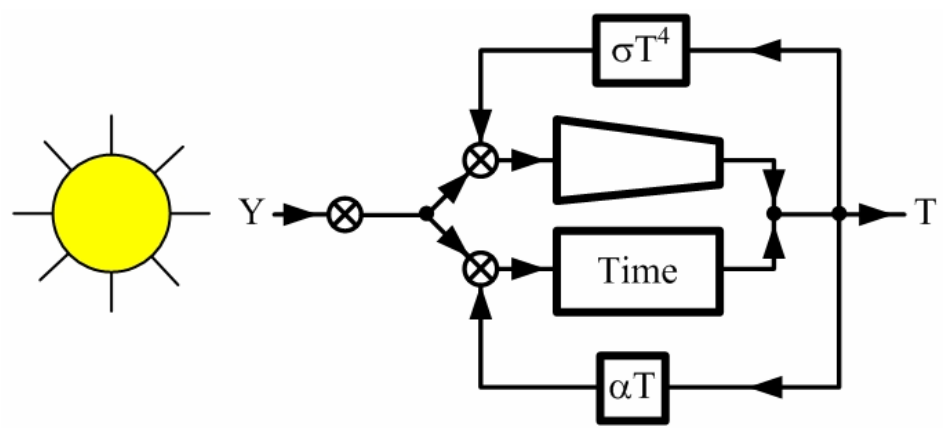

Fig. 10. Hypothetical structural diagram of the global heat transfer.

Here parameter $Y$ is the solar intensity variation cycles influencing the global temperature. The Earth appears as the object of temperature variations provided by two channels for heat removal. First of them is an inertialess channel for infra-red radiation, which, responding to temperature, removes radiative heat through the limiting absorptive windows. The feedback of this channel, in practice does not function, since its carrying capacity is entirely limited. The second channel is a two-step convective-radiative one, which unlimitedly, by convection, transfers heat to higher troposphere layers not containing water molecules by-passing the mentioned limiting absorptive windows. From these layers the heat is transferred into the space in a two-stage process within a range of the wavelengths corresponding to a cooled environment. At the temperature change by $\Delta T$ the heat transfer increases by $\Delta E$, which causes temperature fall.

All this evidences that the convective channel has a stabilizing negative feedback and, therefore, plays an active role in limitation of temperature changes. 


\title{
9. CONCLUSIONS
}

To a mean temperature of $+15{ }^{\circ} \mathrm{C}$ that is considered comfortable for the Earth life there correspond approximately $60 \%$ of the heat received from the Sun and reflected to the space. Since the transparency of the infra-red channel is limited by the "windows" absorbing green-house gases (mainly water molecules), this channel cannot ensure such heat transfer. There are good grounds to suggest that this function is fulfilled by the second by transparency heat transfer channel - the convective one, with its powerful vertical air streams, which unlimitedly transfers the rest heat to the waterless upper troposphere layers by-passing the absorption windows. From there the heat is radiated into the space unimpeded, in a two-stage process, at the IR wavelengths corresponding to the temperature of cooled air in compliance with Planck's equation. As a result, the convective channel fulfils the function of stabilizing the global temperature reducing by half its changes in compliance with the static characteristic curve of heat transfer determined by Newton's law.

\section{REFERENCES}

1. Barkans, J., Zicmane, I. (2005). Peculiarities of annual flows of world's rivers. (with D.Zalostiba participation (\$8.3.chapter)) World Energy Council, Nacional Committee of Latvia. Riga: RTU

2. Barkans, J., Zalostiba, D. (2008). View of climate changes based on the wavelet analysis of solar intensity, Riga: Latvian Journal of Physics and Technical Sciences, vol. 1 (44), 3-11.

3. Chumichow, S.A. (2002). Climate of golocen. Institute of low temperature science, Hokkaido University, Sapporo 060-0819 (Japan).

4. Farmer, C.B., Norton, R.H. IR Spectrum of Sun and Earth Atmosphere, Available at http://en.wikipedia.org/wiki/Greenhouse gas

5. Тонков, М.В. (2001). Спектроскопия парникового эффекта, Соросовский образовательный журнал. Том 7 №10. с. 52-58

6. Dr. Heinz Hug. The Climate Catastrophe - A Spectroscopic Artifact? Available at http://www.john-daly.com/artifact.htm.

7. Федотова, В.Д. Общзая цииркуляциия атмосферы. Pеeјаms

http://www.primpogoda.ru/articles/prosto_o_pogode/obwaya_cirkulyaciya_atmosfery/

\section{KLIMATS KĀ ZEMES SILTUMA NODOŠANAS FAKTORS}

\author{
J. Barkāns, D. Žalostība \\ Kopsavilkums
}

Darbā parādīts, ka Zemes vidējo temperatūru un, tātad, klimatu, nosaka galvenokārt Saules saņemtā siltuma atstarošanas apjoms. Siltums, kas tiek atstarots tieši ar radiāciju caur troposfēru ir nepietiekošs Zemes dzīvei nepieciešamās temperatūras uzturēšanai, jo to ierobežo siltumnīcas gāzu radīti (galvenokārt ūdens molekulu) absorbcijas logi. Nepietiekošais siltums tiek atdots ar vispārējās gaisa cirkulācijas sastāvdaļas - stiprām vertikālām konvekcijas gaisa plūsmām. Tās 
siltumu, ierobežotu tikai ar N̦ūtona likumu, nogādā uz ūdens molekulu nesaturošiem augšējiem troposfêras slāṇiem, no kurienes tas ar atdzisušai videi atbilstošiem infrasarkanā starojuma viḷnu garumiem tiek praktiski neierobežoti izkliedēts. Konvekcija, kas pateicoties N̦ūtona likumam rada negatīvu atgriezenisko saiti, stabilizē Zemes temperatūras izmainas procesu, divkārši samazinot tās izmainās apmērus.

04.04 .2009 